\title{
Evaluation of the Level of Biosecurity Measures Adopted in Broiler Farms Based on Manure Bacterial Load Examination in Khartoum State, Sudan
}

\author{
Mona Ahmed Babiker Ahmed, Atif Elamin Abdelgadir, and Hayfa Mohammed Ismail
}

\section{ABSTRACT}

This study was conducted to evaluate the level of adopted biosecurity measures in broiler farms based on manure bacterial load examination in Khartoum State, Sudan. To achieve the goal, a cross sectional study was conducted. Data and manure samples were collected from January to September 2018 from 12 close system broiler farms according to Nonprobability Multistage Cluster Sampling Method in Khartoum, Khartoum North (Bahri), and Omdurman localities (4 for each). A standardized questionnaire was also conducted and used for data collection. A total of $\mathbf{1 2}$ manure samples were collected from one chosen broiler house in each farm to check the TVCs. All collected Data were subjected to descriptive and analytical statistic such as Chi square and ANOVA using SPSS. The Results of external biosecurity measures revealed that half of the total farms examined $(50 \%)$ were at a distance between $500 \mathrm{~m}$ to $1 \mathrm{~km}$ from the nearest poultry farm. The same percentage was obtained for no manure spreading from neighboring farms. However, frequent passage of other farms vehicles via near public road was reported in $\mathbf{5 0 \%}$ of participating farms. The internal biosecurity results showed that all the examined farms $(\mathbf{1 0 0 \%})$ prohibiting manure storage beside $\mathbf{7 5 . 0 \%}$ of them remove the manure through the dirty area. Furthermore, workers protective wearing when contact waste and hygiene practicing after removing waste sometimes practiced by $75.0 \%$ of the participant farms. The mean of bacterial TVCs in manure samples was found below the cut-off level $(6.01 \pm 0.78 \mathrm{cfu} / \mathrm{g})$ with $95 \%$ confidence intervals of 4.48-7.37, 5.20-6.79, and 4.39-7.84 and mean TVC of $5.93 \pm 0.90,6.00 \pm 0.50$, and $6.11 \pm 1.08 \mathrm{cfu} / \mathrm{g}$ for Khartoum, Khartoum North, and Omdorman, respectively. No significant difference was obtained for log means of bacterial TVCs and farm location (F value $=\mathbf{0 . 0 4 7}$ and $P$-value $=0.955$ ). In conclusion, despite that the bacterial counts in manure samples were below the cut-off level, poor hygienic practices were detected. Formulation of suitable procedures and regulations by official authorities for implementing biosecurity measures is recommended.

Keywords: Broiler farms, external biosecurity, internal biosecurity, Manure Sudan.

\section{INTRODUCTION}

Highlight a section that you want to designate with a Sudan is known as one of the countries in the region with potential competitive poultry production sector. Poultry farming in Sudan is also growing rapidly and became important source of food and income [1]. In 2002, Sudan had a net import of 490000 live chicks and the number of birds in the country was estimated at 45.3 million [2]. In 2009, estimation of the broiler farms in Sudan was 164 which were distributed in Khartoum (39\%), Khartoum North (37\%), and Omdurman (24\%) [3]. Biosecurity is an initiative step to keep health and ensure continuous production of safe poultry and poultry products, otherwise it will negatively affect the quality and quantities of these
Published Online: September 15,2021

ISSN: $2736-6596$

DOI : 10.24018/ejvetmed.2021.1.2.11

Mona Ahmed Babiker Ahmed

Department of Preventive Medicine and Veterinary Public Health, Faculty of Veterinary Medicine, University of Khartoum, Sudan.

Atif Elamin Abdelgadir*

Department of Preventive Medicine and Veterinary Public Health, Faculty of Veterinary Medicine, University of Khartoum, Sudan.

(e-mail: atifvet@yahoo.com)

Hayfa Mohammed Ismail

Department of Preventive Medicine and Veterinary Public Health, Faculty of Veterinary Medicine, University of Khartoum, Sudan.

*Corresponding Author products, so it is important to be secured protected and have adequate medical coverage [4]. Developed poultry industries are characterized by on-site biosecurity programs, which are designed and supported by close veterinary and laboratory surveillance to prevent or minimize introduction of infectious diseases and provide a quick recognition of the emerging disease. However, in countries where poultry production sites still lack adequate biosecurity programs and access to competent veterinary services with laboratory backup, the economic consequences and time needed to identify, control, and resolve the problem are much greater. As a result, one or more emerging pathogens become established and continue to pose a threat as an endemic infection [5].

Adoption of biosecurity in poultry farms requires more 
information on current status level of biosecurity, and a better understanding of the factors that influence the adoption of biosecurity measures. Biosecurity measures in poultry production is considered as an initiative step to help keeping birds healthy and ensure continuous production of safe poultry meat and it should be implemented and enhanced with the adoption of the principles of Good Hygiene Practices (GHPs), Good Manufacturing Practices (GMPs) [6].

Unfortunately, poultry production in Sudan mostly is identified to have inadequate care and health, inappropriate housing and poor knowledge of poultry management and unsafe poultry meat production processing [4],[7]. Biosecurity procedures should be implemented with the objective of preventing the introduction and dissemination of infectious agents in all poultry production chain and enhanced with the adoption and implementation of the principles of Good Manufacturing Practices (GMPs), Good Hygiene Practices (GHPs), and other biosecurity and food safety insurance systems [8], [9]. Therefore, this study was designed to evaluation of the Level of Biosecurity Measures Adopted in Broiler Farms Based on Manure bacterial Load Examination in Khartoum State, Sudan.

\section{MATERIALS ANDMETHOD}

\section{A. Study Site}

The current study was carried out in Khartoum State which is located at the central part of Sudan including three large localities: Khartoum, Bahri (Khartoum North), and Omdurman with an estimated population of over 8 million people. In general, Khartoum is considered as one of the hottest major cities in the world, with annual mean temperatures hovering around $30^{\circ} \mathrm{C} \quad\left(86^{\circ} \mathrm{F}\right)$ [10]. Agricultural livestock production includes beef, sheep, dairy and poultry farming. Most of the poultry production in Sudan centered in and around Khartoum State which is estimated as $90 \%$ of Sudan's poultry production [11].

\section{B. Type of Poultry Production Systems in the Study Site}

There are two poultry production systems in Khartoum State, traditional type, and commercial type. The current study targeted closed system broiler farms and their slaughterhouses in the three localities in Khartoum State: Khartoum, Omdurman, and Bahri.

\section{Study Design}

Cross sectional study was used mainly to evaluate the Level of biosecurity measures adopted in broiler farms based on manure bacterial load examination in Khartoum State, Sudan using questionnaire and laboratory tests.

\section{Sampling Method and Sample Size}

Sampling was done at different levels (site, farms, sample, respondents) from January to September 2018. Hence, Non-probability Multistage Sampling Method was used according to support of the owners as described by [12]. This method was used for both samples collection and questionnaire survey. The study covered three localities in Khartoum State: Khartoum, Omdurman, and Bahri. Twelve closed system broiler farms and their slaughterhouses were included on voluntary basis, four farms from each locality. The respondent farms and their slaughterhouses were visited to capture the biosecurity status and current microbiological situation through questionnaire, samples collection, and observation of the investigator. Moreover, a total number of twelve manure samples from the broiler houses were collected to evaluate the bacterial load (one for each farm).

\section{E. Data Collection Using Questionnaire}

This study was partially based on qualitative, semistructured questionnaire. to assess the extent of implementing requirements of biosecurity measures in respondent farms.

\section{F. Collection of Manure Samples}

The samples were collected according to standard microbiological procedures [13]. Twelve individual poultry manure samples were taken from all respondent broiler farms. A total weight of $25 \mathrm{~g}$ of manure from each sampled house was collected by using a disposable wooden applicator to scoop samples into a sterile sampling container. Finally, the samples were stored in a cool box $\left(4^{\circ} \mathrm{C}\right)$ and transported immediately to the laboratory for further analysis [14].

\section{G. Bacterial Total Viable Counts (TVCs)}

Bacteria TVCs in a manure sample was made according to [14]. The manure solution was prepared by adding one gram of manure to $10 \mathrm{~mL}$ of normal saline. Glass beads were added to the mixture to facilitate dispersion of manure during mechanical shaking for 20 minutes. The resulting supernatant was diluted $(1: 10)$ up to an approximate concentration of $10^{-3}$ to $10^{-4} \mathrm{cfu} / \mathrm{cm}^{2}$ by transferring $1 \mathrm{~mL}$ from first dilution $\left(10^{-1}\right)$ to the second test tube (test tube contains $9 \mathrm{~mL}$ of sterile distilled water) ( $2^{\text {nd }}$ dilution or $\left.10^{-2}\right)$ then from second test tube $1 \mathrm{ml}$ was transferred to the third tube ( $3^{\text {rd }}$ dilution or $10^{-3}$ ) and so on up to the $6^{\text {th }}$. The dilutions were prepared and kept daily at $4{ }^{\circ} \mathrm{C}$ until they were used for the subsequent tests. After serial dilution of samples at 1 in 10 concentrations, samples were cultured on solid nutrient agar plates. The inoculated plates were incubated at $37^{\circ} \mathrm{C}$ for 24 hours, after which the bacteria of different samples were grown to form many colonies on the nutrient agar media. Plates that counted between 30 and 300 colonies were selected. Finally, the number of colony forming units per millilitre $\left(\mathrm{cfu} / \mathrm{cm}^{2}\right)$ was calculated:

\section{Total number of bacteria per $\mathrm{cm} 2=$ number of colonies counted $*$ dilution factor.}

The critical level of bacterial count is $10^{7} \mathrm{cfu} / \mathrm{g} .\left(\log 10^{7}\right.$ $=7 \mathrm{cfu} / \mathrm{g})[14]$.

\section{H. Data Analysis and Management}

Statistical Package for Social Sciences (SPSS) version 19.0 for Windows was used for data analysis Descriptive statistics such as frequency and percentage were used for variables and all results were presented in tables and graphs. 


\section{RESULTS}

\section{A. External Biosecurity in Broiler Poultry Farms}

Nine broiler farms $(75.0 \%)$ reported proper disposal of wastes through dirty area. Good hygiene regarding storage and removal of waste was also observed in all respondents' farms $(100 \%)$. Furthermore, workers hygiene revealed that $58.3 \%$ of them sometimes used protective wear beside washing and disinfecting their hands after removing waste, Also, the same percentage was obtained for prohibiting manure storage $12(91.7 \%)$ (Table I). Half of the total farms examined $(50 \%)$ were at a distance between $500 \mathrm{~m}$ to $1 \mathrm{~km}$ from the nearest poultry farm. Also, the same percentage was obtained for no manure spreading from neighboring farms. However, frequent passage of other farms vehicles via near public road was reported in $50 \%$ of participating farms (Table II). The internal biosecurity results showed that all the examined farms prohibiting manure storage beside $75.0 \%$ of them remove the manure through the dirty area. Furthermore, workers protective wearing when contact waste and hygiene practicing after removing waste sometimes practiced by $75.0 \%$ of the participant farms.

TABLE I:EVALUATION Of INTERNAL BIOSECURITY MEASURES IN BROILER

\begin{tabular}{lc}
\multicolumn{1}{c}{ FARMS } & \\
\hline \hline Parameter & Frequency $\%$ \\
\hline \hline Removal of manure through the dirty area & \\
1.Yes & $9(75.0 \%)$ \\
2. No & $3(25.0 \%)$ \\
Cleaning disinfecting of houses after each cycle & \\
1.Yes & $11(91.7 \%)$ \\
2. No & $1(08.3 \%)$ \\
Prohibiting manure storage & $12(100.0 \%)$ \\
1.Yes & $0(100.0 \%)$ \\
2. No & \\
Sanitary transition period after each cycle & $2(16.7 \%)$ \\
1. $<3$ & $3(25.0 \%)$ \\
2. 3-8 & $7(58.3 \%)$ \\
3. $>8$ & $4(33.3 \%)$ \\
Microbiological testing of sanitizers efficacy & $9(75.0 \%)$ \\
1. After each cycle & \\
2. Sometimes & $3(25.0 \%)$ \\
Hygeinic measures of manure trucks & $9(75.0 \%)$ \\
1.Yes & \\
2. No & $8(66.7 \%)$ \\
Well closed manure removal area & $4(33.3 \%)$ \\
1. Yes & $7(58.3 \%)$ \\
2. No & $5(41.7 \%)$ \\
Regular manure lab testing & $4(33.3 \%)$ \\
1. After each collection & $7(58.3 \%)$ \\
2. Sometimes & $1(08.3 \%)$ \\
Workers protective wear when contact waste & $5(41.7 \%)$ \\
1. Always & $7(58.3 \%)$ \\
2. Sometimes & \\
3. Never & \\
Workers hygiene after removing waste & \\
1. Always & \\
2. Sometimes & Never \\
\hline \hline
\end{tabular}

* The total number of respondent farms was twelve.

\section{A. Bacterial Load Analysis of Manure Samples of Broiler} Farms

Based on the cutoff level of Total Viable Counts (TVCs) of contaminant bacteria in manure sample [15], the overall $\log$ mean of total bacteria concentration was $6.01 \mathrm{cfu} / \mathrm{g}$ which was below the cut-off level. For each locality, the results obtained showed that the log means of TVCs were
$5.93,6.00$, and $6.11 \mathrm{cfu} / \mathrm{g}$, with $95 \%$ confidence intervals of 4.48-7.37, 5.20-6.79, and 4.39-7.84 for Khartoum, Bahri, and Omdorman, respectively. Statistically, no significant difference was observed for log means of bacterial TVCs and different sites $(\mathrm{F}$ - value $=0.047$ and $\mathrm{p}$-value $=0.955)$. The results are shown in Table III and Fig. 1.

TABLE II:Evaluation OF EXTERNAL BIOSECURITY MEASURES IN BROILER FARMS RELATED

\begin{tabular}{lc}
\hline \hline Parameter & Frequency $\%$ \\
\hline \hline Distance of the nearest poultry farm & $3(25.0 \%)$ \\
1. $<500 \mathrm{~m}$ & $6(50.0 \%)$ \\
2. $500 \mathrm{~m}-1 \mathrm{~km}$ & $3(25.0 \%)$ \\
3. $>1 \mathrm{~km}$ & \\
Manure storage in neighbouring farms & $0(00.0 \%)$ \\
1. Yes & $11(91.7 \%)$ \\
1. No & $1(08.3 \%)$ \\
2. Sometimes & \\
Manure Spreading from neighboring & \\
farms & $4(33.3 \%)$ \\
1. Many times & $2(16.7 \%)$ \\
2. Sometimes & $6(50.0 \%)$ \\
3. Never & \\
Other farms vehicles passage via public & \\
road & $6(50.0 \%)$ \\
1. Many times & $5(41.7 \%)$ \\
2. Sometimes & $1(08.3 \%)$ \\
\hline \hline
\end{tabular}

*The total number of respondent farms was twelve.

TABLE III:DESCRIPTIVE STATISTICS OF BACTERIAL LOG TVCS OF MANuRE SAMPLES Of BROILER Houses In KHARTOUM State, SudAN

\begin{tabular}{cccccc}
\hline \hline Location & $\begin{array}{c}\text { No. of } \\
\text { farms }\end{array}$ & Mean & $\begin{array}{c}\text { Std. } \\
\text { deviation }\end{array}$ & $\begin{array}{c}\text { Std. } \\
\text { error }\end{array}$ & $\begin{array}{c}95 \% \\
\text { confidence } \\
\text { interval }\end{array}$ \\
\hline \hline Khartoum & 4 & 5.93 & 0.90 & 0.45 & $4.48-7.37$ \\
Bahri & 4 & 6.00 & 0.50 & 0.25 & $5.20-6.79$ \\
Omdorman & 4 & 6.11 & 1.08 & 0.54 & $4.39-7.84$ \\
Total & 12 & 6.01 & 0.78 & 0.22 & $5.51-6.51$ \\
\hline \hline
\end{tabular}

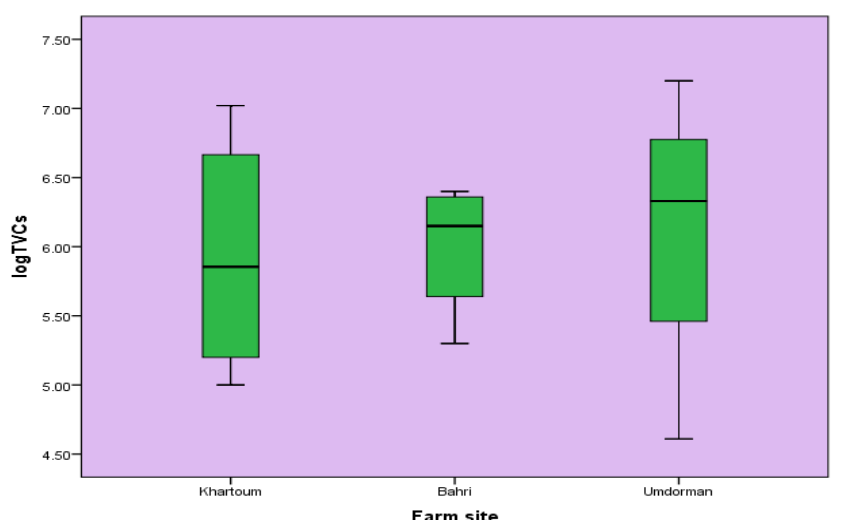

Fig.1. Association between mean log TVCs of manure samples anddifferent sites of farms in Khartoum State, Sudan.

$*$ The cut-off level $=10^{7} \mathrm{cfu} / \mathrm{g}\left(\log 10^{7}=7 \mathrm{cfu} / \mathrm{g}\right)[15]$. Mean Square $=0.035$ F-value $=0.047 \mathrm{p}$-value $=0.955>0.05$ (Not significant).

\section{DiscUSSION}

However, higher level of biosecurity regarding transport vehicle hygiene implemented by mostof the investigated farms. These findings were supported by [16] in their study which was carried out in Bahri locality, Sudan to determine the efficacy of cleaning and disinfection of broiler farms between production cycles and to evaluate the present biosecurity measures in poultry houses during rest period. 
During this study, it is found that half of the total farms examined were at a distance between $0.5-1 \mathrm{~km}$ and complained from frequent passage of neighboring farms vehicles via near public road. The same finding was reported by Mahmoud et al. [17] who found that the distance to the nearest farm was more than $500 \mathrm{~m}$ in $75.5 \%$ of the respondents of the surveyed farms. According to [18], there was no set distance that will uniformly eliminate the risk of disease transfer. However, to reduce the likelihood of airborne transmission between poultry farms, the distance to the nearest neighbor should be at least $500 \mathrm{~m}$ and preferably $>1 \mathrm{~km}$. This role should be applied not only nearby other industrial poultry farms but also backyard poultry which can pose a risk. It was agreed in some studies that, when poultry farms are close to each other, attention should be paid to the predominant wind direction [19], [20].

The current study showed that most of the targeted farms $(91.7 \%)$ were restricted to prohibiting manure storage and keeping "backyard" poultry in the targeted farms, preventive measures application of material supplied, not keeping other animals for farming, and no equipment's sharing with other farms. In consistent with [19], no equipment, weeds, or waste should be piled up against the outer stable walls and feed should be stored in a vermin-free place to discourage rodents from nesting in the vicinity of the stables. The same findings were also stated by [17]. They concluded that, in Khartoum State, the close system was more secure than other rearing system indicating that management regarding biosecurity is highly implemented, also larger facilities are often assumed to implement more advanced biosecurity measures.

The findings of the presented study indicated that proper waste disposal and dead bird removal were implemented in most of the tested farms. However, low restriction to protective wearing beside hands washing and disinfecting after removing dead birds were observed or contact with waste. The same findings were also noted by [17] who found that $68.9 \%$ of farmers separated sick birds from health birds and $95.5 \%$ of respondents used burring for disposable of dead birds and just two farms (4.4\%) left dead birds thrown. In contrast, [21] conducted a study evaluating the disposal of manure and dead birds in poultry farms in Khartoum State, Sudan and they found that $77.03 \%$ of farms under study disposed their manure and dead birds improperly. The author recommended that dead birds must be in appropriate site either on or preferably off farm. Almost similar findings were obtained by [22] in their study that aimed to provide information on the present biosecurity measures in industrial broiler farms and to measure farmers' attitudes and opinions towards biosecurity in west Java, Indonesia found that 24 farmers (96\%) separated sick birds from healthy birds andburnedorburied them for disposable and just $4.4 \%$ leftdead birds thrown away, while [25] in a study to evaluate biosecurity status in commercial broiler farms in Sri Lanka, found that $45 \%$ of the farmers included in their study were practicing burring the carcasses and $26 \%$ used septic pit for disposal while $29 \%$ of farmers threw the dead birds in the farm carelessly without realizing any risk. Previous researches by [23], [24] stated that dead birds must be removed once or twice daily if mortality is high. The reason behind good practicing regarding disposal of dead birds and manure in most of the studied farms is that the farmers are highly aware that dead birds and waste materials are potential sources of contamination. In addition, it was noticed that most farmers sell litter directly after removal to make extra profit.

Hence the level of microbial contamination in poultry manure is one of the most important sanitary and hygienic indicators in broiler farms, the results obtained by the present study showed means bacterial Total Viable Counts (TVCs) below the cut-off level $(6.01 \pm 0.78 \mathrm{cfu} / \mathrm{g})$ which was reported by [15]. This results was consistent with observations by [26] in his study inMississippi State, USA to determine the distribution of aerobic, anaerobic and coliform bacteria in commercial broiler farms at three different bedding depths which revealed TVCs of6.71 $\pm 0.083 \log \mathrm{cfu} / \mathrm{g}$. Compared to previousstudies, our results were lower than the results reported by [27] and [28] who reported 9.0 and $8.01 \mathrm{cfu} / \mathrm{g}$ respectively in their studies to investigate some microbiological and chemical properties as well as the incidence of microorganisms associated with poultry manure of poultry wastes manure to evaluate the hygienic status in broiler farms. The observed low microbial counts in broiler manure in the presented study also disagrees with the findings of [29] who conducted a study in India and found that the predominant microflora of poultry manure was bacteria whose population was $72 \times 10^{9} \mathrm{cfu} / \mathrm{g}$ and [30] who stated that microorganisms in poultry manure were present at $250,000 \mathrm{cfu} / \mathrm{g}$. The variation in the previous results could be due to differences of disinfection protocols practiced.

It is clearly observed that there are lacks data in the available literature about number of cultivable microorganisms in poultry manure [28]. This fact enforces us to discuss our findings in a comparative aspect as with data for poultry litter contamination in broiler houses since poultry litter consists mainly of poultry manure and bedding materials, feather, and split feed and can be indicative for manure contaminants level [31]-[33]. Based on the previous facts, the current study was also lower than these recorded by [17], [30], [31], [34], [35] who showed that microbial concentrations in poultry litter exceeded $1010 \mathrm{cfu} / \mathrm{g}$.

We concluded that despite that the bacterial counts in manure samples were below the cut-off level, poor hygienic practices that leads to contaminated poultry meat was detected. It is recommended that education and training programs of workers on proper and hygienic method of different biosecurity practices regarding broiler production should be implemented.

\section{REFERENCES}

[1] F. O. Elghouth, O. E. Yassin, T. E. Angara, A. Wahab, "Some Management and Economic Aspects of Broiler Production in Khartoum State," Journal of Agricultural and Veterinary Sciences, 1(14): 80-85, 2013.

[2] A. D. Ahmed, "Hematological and Biochemical Profile of Blood of Indigenous Chicks in Sudan," Master Thesis, University of Khartoum, 2009.

[3] Agricultural census - 2008, Ministry of Agriculture, Animal Resources and Irrigation. Khartoum State, Sudan, 2009.

[4] H. A. Jensen, "Paradigm and Visions: Network for Poultry Production in Developing Countries," In: F Dolberg and P H Petersen (eds.) Poultry as a Tool in Poverty Eradication and Promotion of Gender 
Equality Proceedings of a workshop, March 22-26, 1999, Tune Landboskole, Denmark.

[5] T. J. Baugst, M. A. Johnson, "Avian Infectious Iaryngotracheitis: Virus-host Interactions in Relation to Prospects for Eradication," Avian Pathol, 24(3): 373-391, 1995.

[6] M. F. Sulieman, "Egg Characteristics, Genetic and Phenotypic Relationships of Body Weight at Various Ages in Indigenous Chickens," Master Thesis, University of Khartoum, 1996.

[7] H. A. Ahmed, "Bacterial Contamination of Chicken Carcasses at Abattoir in Khartoum State, Sudan," A dissertation Submitted to Sudan University of Science and Technology, 2014.

[8] J. B. Trevor, "Poultry Health and Disease Control in Developing Countries," Food and Agriculture Organization of the United Nations, Poultry Development Review, 2006. http://www.fao.org/3/al729e/al729e00.pdf.

[9] J. Sture, S. Whitby, D. Perkins, "Biosafety, Biosecurity and Internationally Mandated Regulatory Regimes: Compliance Mechanisms for Education and Global Health Security," Med ConflSurviv, 29(4): 289-321, 2013.

[10] R. S. I. Hamed, "Finding the Optimal Location for New ATM Using GIS Technologies," Ph.D. Thesis,Sudan University of Science and Technology, 2016.

[11] H. A. Wagge Alla, "Dimensions and Impact of Application of Extension, Laws, and Regulations, Applied Research and Quality Control on Poultry Industry in Khartoum State," Ph.D. Thesis, Sudan Academy for Sciences, Khartoum, Sudan, 2011.

[12] M. Thrusfield, Veterinary Epidemiology. $3^{\text {rd }}$ ed. Black well Science Ltd. United Kingdom, 2007.

[13] J. G. Cappuccino, N. Sherman, "Microbiology: A Laboratory Manual," $6^{\text {th }}$ Edition, San Francisco: Pearson/Benjamin Cummings, 2002.

[14] K. L. Jennifer, L. A. Beaudette, M. Hart, P. Moutoglis, J. N. Klironomos, H. Lee, J. T. Trevors, "Methods of Studying Soil Microbial Diversity (Review)," Journal of Microbiological Methods, 58(2): 169-188, 2004.

[15] J. Skora, K. Matusiak, P. Wojewodzki, A. Nowak, M. Sulyok, A. Ligocka, M.Okrasa, J. Hermann, B. Gutarowska, "Evaluation of Microbiological and Chemical Contaminants in Poultry Farms," Int. J. Environ. Res. Public Health, 13(2): 192, 2016.

[16] E. A. Mustafa, H. A. A. Babeker, "Evaluation of the Efficacy of Cleaning and Disinfection in Broiler Farms Between Rest Periods in Khartoum State, Sudan," World Journal of Pharmacy and Pharmaceutical Sciences, 2(7): 109-119, 2018.

[17] M. A. Mahmoud, A. E. Abdelgadir, M. I. Hayfa, "Evaluation of Biosecurity Measures on Broiler farms in Khartoum, Sudan," Journal of Veterinary Medicine and Animal Health, 6(5): 138-144, 2014.

[18] C. Stephen, "Best Practice Management for Meat Chicken Production in New South Wales-Manual 2 (Meat Chicken Growing Management)," NSW Department of Primary Industries, 2012.

[19] S. A. Lister, "Biosecurity in poultry management," In Poultry diseases, WB Saunders, 48-65, 2008.

[20] S. Van Steenwinkel, S. Ribbens, E.Ducheyne, E. Goossens, J.Dewulf, "Assessing Biosecurity Practices, Movements and Densities of Poultry Sites Across Belgium, Resulting in Different Farm Riskgroups for Infectious Disease Introduction and Spread," Prev. Vet. Med., 98(4): 259-270, 2011.

[21] E. A. Mustafa, E. M. Hamad, M. M. O. Elhassan, A. M. Salman, M. M. E. Elsiddig, M. A. Lamyia, "Disposal of Dead Birds and Manure in Poultry Farms under Different Production and Management Systems in Khartoum State, Sudan," World Journal of Pharmacy and Pharmaceutical 7(11): 61-70, 2018a.

[22] E. Sudarnika, Y. Ridwan, A. Z. lya, C. Basri, D. W. Lukman, T. Sunartatie, B. A. Wibowo, A. Sugama, P. G. Hermans, A. J. Nell, "Biosecurity Measures on Broiler Farms in Subang, West Java Indonesia," The $1^{\text {st }}$ Congress of Southeast Asia Veterinary School Association, Bogor, Indonesia, 2010.

[23] T. M. Williams, M. Mboya, H. O. Chadha, "Assessment of Biosecurity Initiatives on Broiler Farms in Khartoum," Sudan. African Journal of Poultry Farming, 4(6): 159-165, 2016.

[24] G. Arzey, I. Littleton, "NSW Biosecurity Guidelines for Free Range Poultry Farm," NSW Department of Primary Industries, Orange, NSW, 2007.

[25] W. M. J. B. Wijesinghe, P. G. J. C. De Silva, S. P. Gunaratne, "Evaluation of Biosecurity Status in Commercial Broiler Farms in Sri Lanka," International Journal of Scientific and Research Publications, 7(4): 2250-3153, 2017.

[26] K. J. Barker, J. L. Purswell, J. D. Davis, H. M. Parker, M. T. Kidd, C. D. McDaniel, A. S. Kiess, "Distribution of Bacteria at Different Poultry Litter Depths," Int. J. Poult. Sci., 9: 10-13, 2010.
[27] M. El-Jalil, A. Zinedine, M. Faid, "Some Microbiological and Chemical Properties of Poultry Wastes Manure After Lactic Acid Fermentation," International Journal of Agriculture and Biology, 10(4): 405-411, 2008.

[28] G. Kostadinova, G. Petkov, S. Denev, Ch. Miteva, R. Stefanova, T. Penev, "Microbial Pollution of Manure, Litter, Air and Soil in a Poultry Farm," Bulg J Agric Sci., 20(1): 56-65, 2014.

[29] S. Devi, C. R. Sharma, K. Singh, "Microbiological Biodiversity in Poultry and Paddy Straw Wastes in Composting Systems," Braz J Microbiol, 43(1): 288-296, 2012.

[30] J. Lu, S. Sanchez, C. Hofacre, J. J. Maurer, B. G. Harmon, M. D. Lee, "Evaluation of Broiler Litter with Reference to the Microbial Composition as Assessed by Using 16S rRNA and Functional Gene Markers," Applied and environmental microbiology, 69(2): 901-908, 2003.

[31] A. S. Tasistro, D. E. Kissel, P. B. Bush, "Spatial Variability of Broiler Litter Composition in a Chicken House," Journal of applied poultry research 13(1): 29-43, 2004.

[32] H. Widell, "Industrial Scale Biomass Combustion Plants: Engineering Issues and Operation," Denmark: Aalborg EnergieTEchnik (AET), 2013.

[33] Z. Chen, X. Jiang, "Microbiological Safety of Chicken Litter or Chicken Litter-based Organic Fertilizer: A Review," Agriculture, 4(1): 1-29, 2014.

[34] M. Terzich, M. J. Pope, T. E. Cherry, J.Hollinger, "Survey of Pathogens in Poultry Litter in the United States," J. Appl. Poult. Res., 9(3): 287-291, 2000 .

[35] K. S. Macklin, J. B. Hess, S. F. Bilgili, R. A. Norton, "Effects of Inhouse Composting of Litter on Bacterial Levels," J. Applied Poult. Res., 15(4): 531-537, 2006. 